\title{
Dynamics of garden birds at a feeding station in a suburban area near Oslo, Norway, 2000-2008
}

\author{
Variationer i fåglarnas antal vid en matningsplats $i$ en trädgård $i$ ett förortsområde \\ nära Oslo, Norge, 2000-2008
}

$\mathrm{KÅRE} \mathrm{ELGMORK} \mathrm{†}$

\begin{abstract}
The presence of birds visiting a feeding site near a villa in a suburban area to the west of Oslo was observed daily at close range during 2000-2008. The bird assemblage consisted of 17 species. Some species were present throughout the year, whereas others occurred during different seasons. Most species showed a stable occurrence from year to year and was little influenced by climatic factors. When comparing with the bird community in a spruce forest about three kilometres away, only $36 \%$ of the forest species occurred regularly at the suburban site, showing a considerable loss of diversity when a forest

is changed into a suburban habitat. Abundance was recorded by the time it took the birds to consume one kilo of sunflower seeds. Maximum consumption occurred during summer and minimum during late winter. A general decrease in consumption in all years of study started during autumn followed by another marked decrease at the time of the first snowfall, which obviously acted as a signal for emigration out of the area.

Department of Biology, University of Oslo, Norway, P.O.Box 1050, 0316 Oslo, Norway.
\end{abstract}

Received 23 November 2011, Accepted 29 November 2011, Editor: S. Svensson

\section{Introduction}

Few long term and detailed bird studies are conducted in gardens all year round. The present paper presents results from nine years of study by approximately daily observations at close range of a bird assemblage in a suburban area near Oslo. This study together with a previous study 1997-1999 (Elgmork 2002) provides continuous data for a period of 12 years. In the 2002-study only the number of weeks the birds were present throughout the year was recorded. After an idea by Cowie \& Hinsley (1988) a study of the consumption rate was made for the years 2002-2008 by recording the time spent to consume one kilo of sunflower seeds.

Comparisons with variation in bird assemblages in national surveys in Norway and Sweden were performed, as well as with the bird assemblage in a nearby climax spruce forest.

Knowledge of garden birds is wanted as a great part of the terrestrial bird fauna belongs to garden birds, and many households provide bird feeders.

† Kåre Elgmork died on 19 November 2011; see p. 189.

\section{Location, surroundings, and climate}

A detailed description of the locality and surroundings is given in Elgmork (2002) and only a short recapitulation will be presented here. The site was situated at Jar in Bærum municipality about midway between contiguous spruce forests to the north-west and the downtown areas of Oslo city to the south-east (Figure 1). The Garden with the feeding site was situated in a contiguous residential area with parks and gardens with many large trees. The feeding site was located only 2.5 meters from a big kitchen window from where the observations were made. A young spruce tree was situated about four meters from the feeding site.

Attacks by predators were negligible. There were only three attacks by Sparrowhawks Accipiter nisus, all of which were unsuccessful.

As stated in Elgmork (2002), data from the Meteorological Institute in Oslo are very representative for the observation site, situated only $6.4 \mathrm{~km}$ away and at about the same altitude. Mean monthly normal temperature and precipitation for the 30year period 1993-1999 was presented in Elgmork (2002). During this period maximum temperature 


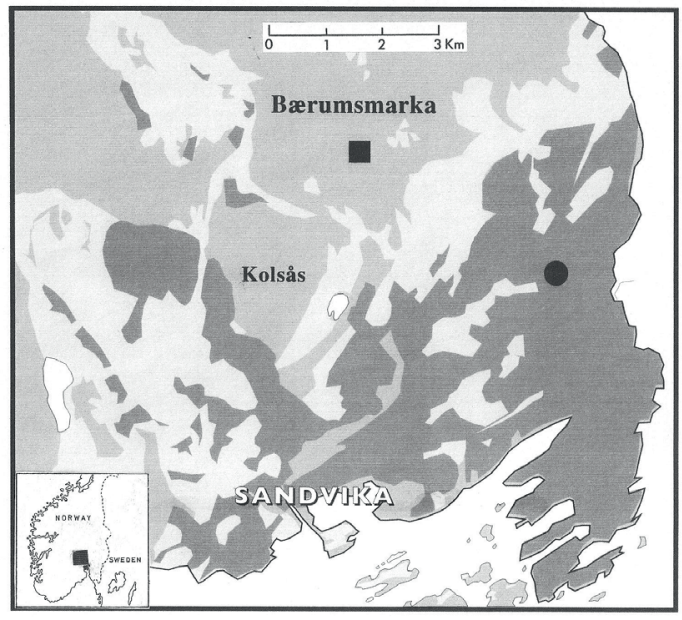

Figure 1. Parts of Bærum municipality with location of the study site (filled circle), and area of the forest bird study of Hogstad (1967) (filled square). Darkest shading: suburban areas to the west of Oslo city. Medium shading: continuous, mostly spruce forests. Lightest shading: agricultural areas. (Redrawn from Aschehoug og Gyldendals Store Norske Leksikon 1996, third volume; permission granted.)

Delar av Barum kommun. Studieområdet markerat med fylld cirkel och Hogstads skogsinventering med fylld kvadrat. Mörk skuggning: bebyggelse. Halvmörk skuggning: sammanhängande skog. Ljusaste: Jordbruksmark.

had in July an average of $16.4^{\circ} \mathrm{C}$. Minimum temperature occurred in January with an average of $-4.3^{\circ}$ C. Precipitation was at a maximum in September with $90 \mathrm{~mm}$ as average. Minimum precipitation occurred in February with an average of 36 $\mathrm{mm}$. Total precipitation for the whole year was $763 \mathrm{~mm}$, in the winter months from December to March mostly as snow.

For comparison with the bird occurrence the mean temperature and precipitation for periods of three months, representing the four seasons, are given in Figure 2. The temperatures were fluctuating among years in autumn and winter, whereas temperatures were more constant during spring and summer. Precipitation was more erratic with exceptionally high values in autumn 2000 and 2006 and in summer 2008.

\section{Methods}

For details on methods I refer to my earlier paper (Elgmork 2002), and only a short recapitulation will be given here. The food presented at the feeding site consisted exclusively of sunflower seeds
Mean temperature in seasons

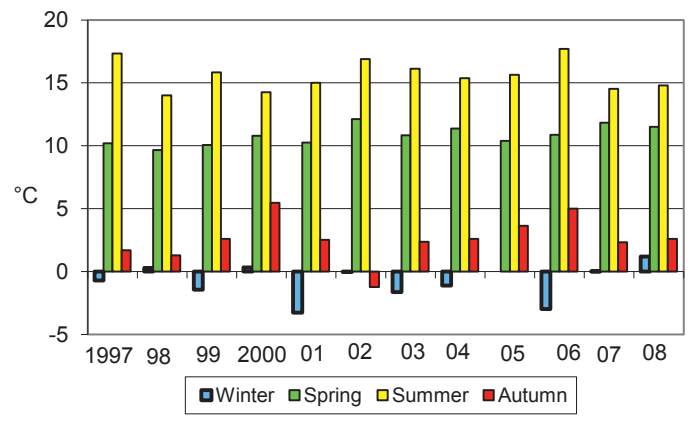

Mean precipitation in seasons

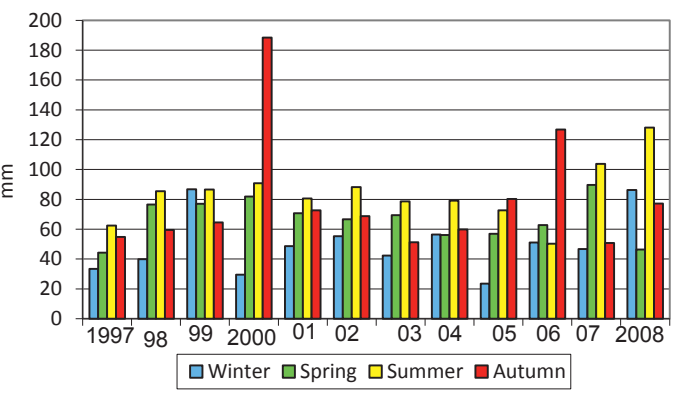

Figure 2. Temperature (upper diagram) and precipitation (lower diagram) during different seasons 1997-2008. Each column represents the mean for three months, here defined as the four seasons.

Temperaturen (övre) och nederbörden (nedre) under de olika årstiderna 1997-2008. Staplarnas höjd anger medelvärdet för tre månader.

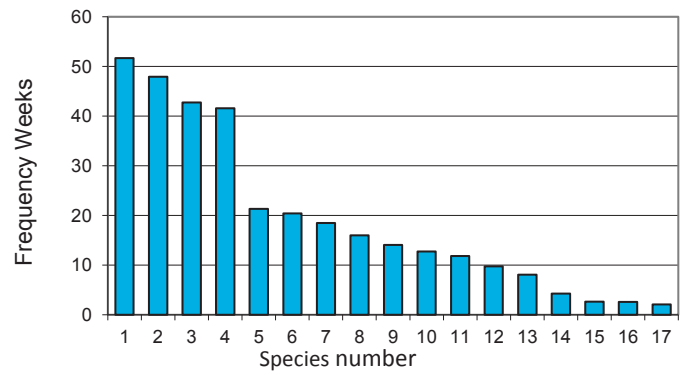

Figure 3. Assemblage of garden birds at the study site and average occurrence (average number of weeks) during the period 2000-2008. 1 Great Tit, 2 Blue Tit, 3 Greenfinch, 4 Tree Sparrow, 5 Nuthatch, 6 Blackbird, 7 Chaffinch, 8 Wood Pigeon, 9 Robin 10 House Sparrow, 11 Collared Dove, 12 Bullfinch, 13 Siskin, 14 Brambling, 15 Redpoll, 16 Yellowhammer, 17 Hawfinch

Fåglarnas genomsnittliga förekomstfrekvens (genomsnittligt antal veckor) 2000-2008 $i$ den studerade trädgården. 
Table 1. Rare species. Number of weeks the species occurred on average per year, 2000-2008.

Sällsynta arter. Frekvens är medelvärdet för antal veckor med förekomst per år 2000-2008.

\begin{tabular}{lll}
\hline Species & Frequency & Season \\
\hline Coal Tit Periparus ater & 0,6 & Nov. Dec. \\
Fieldfare Turdus pilaris & 0,6 & Mar. May Jun. Jul. \\
Sparrowhawk Accipiter nisus & 0,3 & Jul. Oct. Nov. \\
Wren Troglodytes troglodytes & 0,3 & Oct. Nov. \\
Crested Tit Lophophanes cristatus & 0,1 & Nov. \\
Goldfinch Carduelis carduelis & 0,1 & Apr. \\
Hooded Crow Corvus cornix & 0,1 & Nov. \\
Waxwing Bombycilla garrulous & 0,1 & Dec. \\
\hline
\end{tabular}

(Helianthus spp.) and commercial "tit balls", as in the previous study. The balls were given as a supplementary food and were not counted. The tit balls were consumed at a lower rate than the seeds in the food box. Approximately daily observations are available for nine years (2000-2008). The number of visits and rate of consumption at the feeding site rests on the assumption that these parameters are proportional with the density of birds in the surrounding area.

The daily observations were interrupted by a few weeks absence every year, mainly in the autumn. To see if this would give some distorted results, some control observations were made. After the author had been away for 10 to 14 days during three instances, some of the four most common bird species reappeared after a few hours. After a day or two, the assemblage of birds was identical with that before the break. These results indicate that some postponement in feeding has not significantly influenced the results.

\section{Results}

Bird assemblages during 12 years

Frequency of a species is defined as number of weeks that a species was observed during one year.

The bird assemblage studied is presented in Figure 3 arranged after falling frequency during 2000-2008. Frequencies for this period follow approximately the same trend as in the first period 1997-1999 (Elgmork 2002). The four predominant species were the Great Tit Parus major, Blue Tit Cyanister caeruleus, Greenfinch Carduelis chloris, and Tree Sparrow Passer montanus. In addition the Magpie Pica pica was permanently present and the Great Spotted Woodpecker Dendrocopos major sporadically present, but neither was recorded on a weekly basis. The most remarkable difference be- tween the two periods of study is the absence of the Collared Dove Streptopelia decaocto during the years 2005-2008 (Figure 7).

Rare species are defined as species with an average occurrence of less than one week per year for the period 2000-2008 (Table 1). Of the species recorded as rare in 1997-1999, only three were so rare in 2000-2008 (Fieldfare Turdus pilaris, Wren Troglodytes troglodytes, Coal Tit Periparus ater). On the other hand, there were some new species occurring in 2000-2008. An increase in the frequency of the Yellowhammer Emberiza citrinella and Hawfinch Coccothraustes coccothraustes led to these species being removed from the rare species category. The Yellowhammer increased from 0.3 to 3.4, and the Hawfinch from 0.3 to 2.9 weeks presence per year on average between the two study periods. The rare species occurred most frequently from October to December.

\section{Seasonal variation}

The weekly frequencies of birds can be grouped into five categories (Figures 4-8) according to different patterns of occurrence. The four most common species (Figure 4) occurred throughout the year with the Great Tit being present during all weeks except three. The Blue Tit, Greenfinch, and Tree Sparrow were abundant throughout the year. The number of Greenfinches and Tree Sparrows increased from week 26 and 27, and numbers remained high throughout most of the following autumn. This sudden increase was due to the appearance of a new generation of young. The time of first occurrence of young was very stable from year to year, being about a week earlier in the Greenfinch than in the Tree Sparrow.

A group of bird species with irregular occurrence consists of the Robin Erithacus rubecula, Siskin 
Great Tit

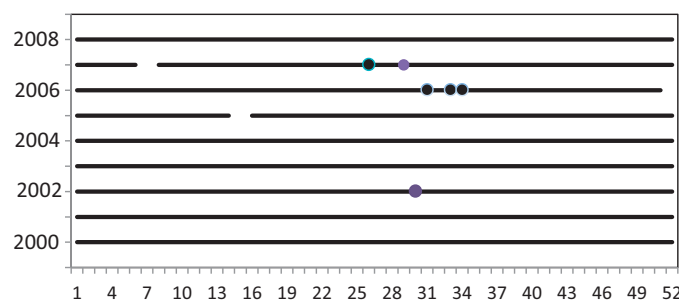

Blue Tit

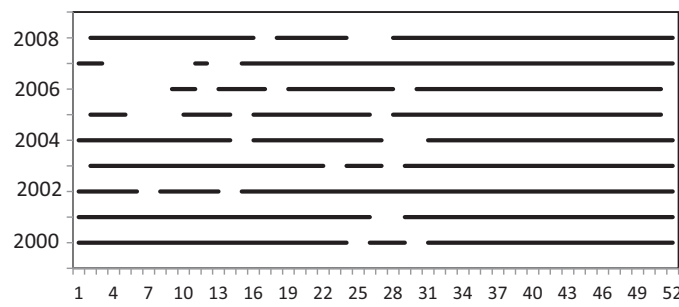

Greenfinch

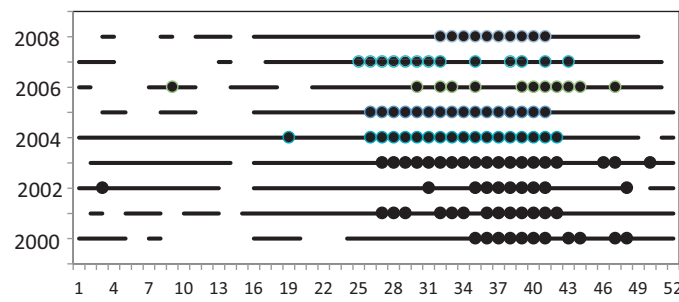

Tree Sparrow

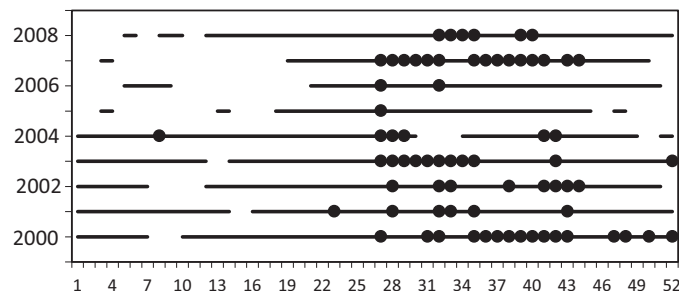

Figure 4. Yearly frequencies of the four most common species. Shortest lines indicate at least one observation in that week. Lines: $<=10$ individuals. Filled circle: $>10$ individuals observed simultaneously that week. Horisontal axis: week number.

Arlig frekvens för de fyra vanligaste arterna. Upplösningen (kortaste linje) motsvarar en vecka. Linje markera 10 eller färre individer. Fylld cirkel anger fler än 10 individer den veckan. Horisontella axeln anger veckonummer.
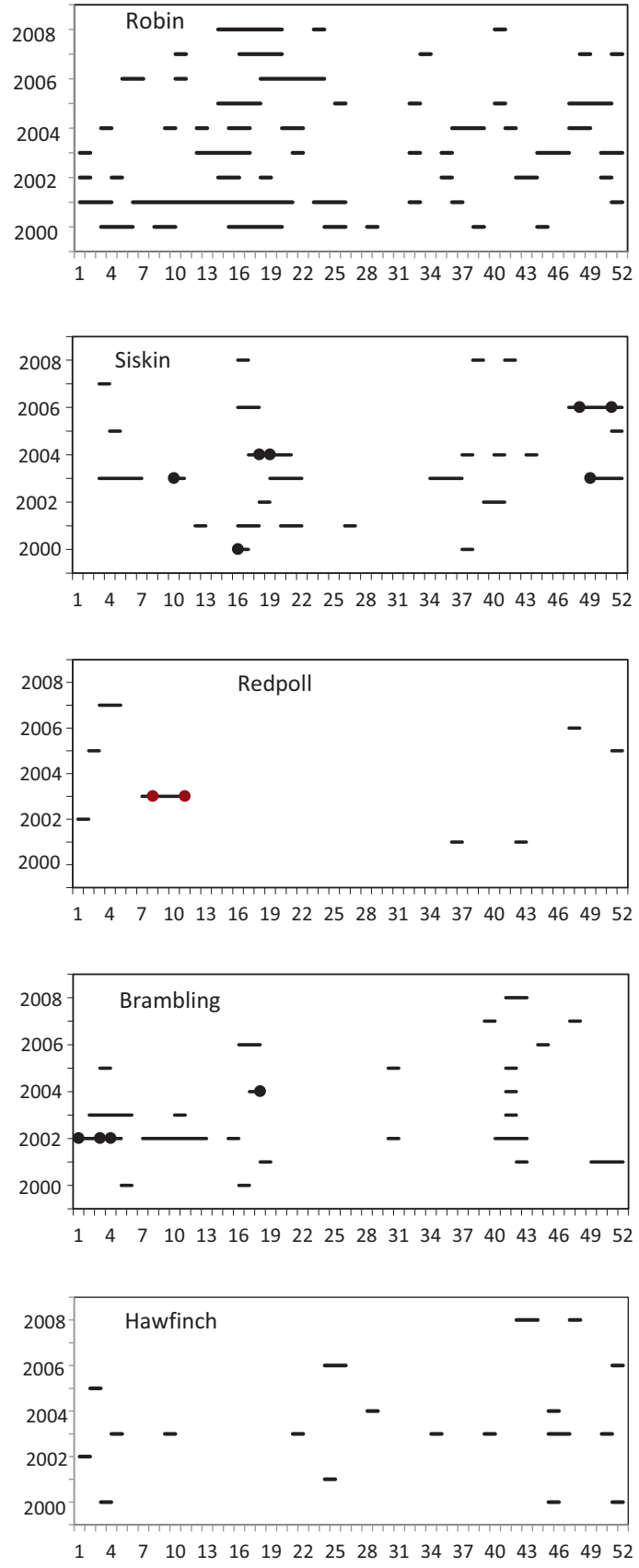

Figure 5. Yearly frequencies of species with scattered incidence. Legend as in Figure 4.

Arlig frekvens för arter med spridd förekomst. Förklaring som i Figur 4. 

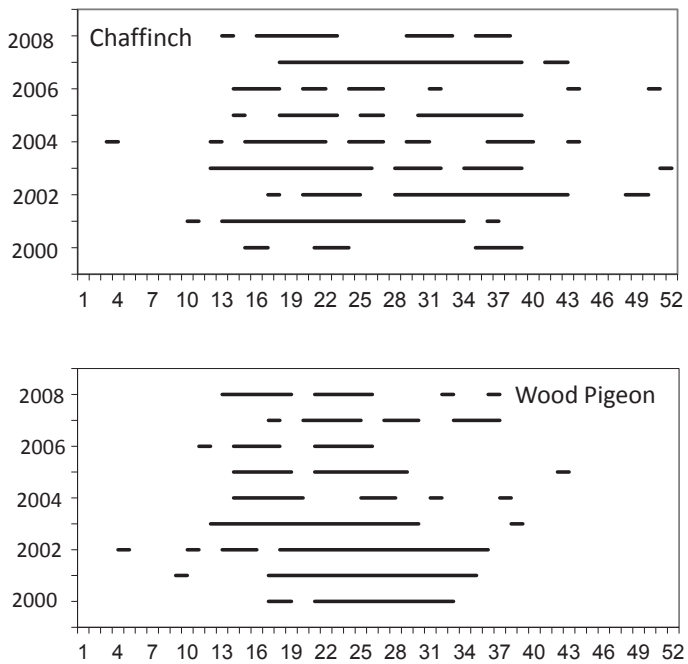

Figure 6. Yearly frequencies of the two truly migrating birds. Legend as in Figure 4.

Arlig frekvens för två äkta flyttfåglar. Förklaring som $i$ Figur 4.

Figure 7. Yearly frequencies of species present primarily during summer and autumn. Legend as in Figure 4.

Àrlig frekvens för arter som registrerades främst sommar och höst. Förklaring som i Figur 4.

Carduelis spinus, Redpoll Carduelis flammea, Brambling Fringilla montifringilla, and Hawfinch (Figure 5). All except the Robin and Hawfinch are invasion species occurring at large numbers at irregular times of the year. At the end of April 2004 both the Siskin and the Brambling occurred in large numbers simultaneously.

Species primarily present during spring and summer were the Chaffinch Fringilla coelebs and Woodpigeon Columba palumbus (Figure 6), whereas the Collared Dove, House Sparrow Passer domesticus, and Nuthatch Sitta europaea were found during summer and autumn, and sparsely also during the winter (Figure 7). Species occurring primarily during winter and spring were Blackbird Turdus merula, Bullfinch Pyrrhula pyrrhula, and the Yellowhammer (Figure 8). The Nuthatch and Blackbird were present in the general area all year but appeared on the feeding site particularly in autumn and winter (Nuthatch) and winter and spring (Blackbird). This variation throughout the year is most likely due to a shift in food preference since
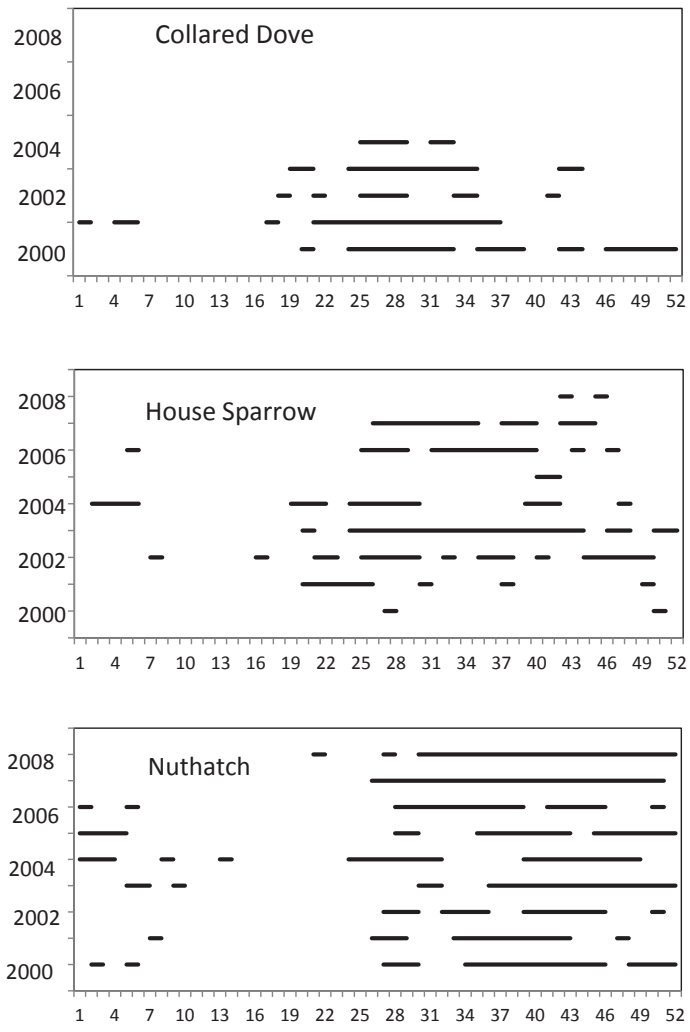

both species prefer food from the feeding site during winter and spring when other food is absent or extremely scarce.

Characteristic for the Bullfinch is a lower frequency in the last three years, and an interrupted occurrence indicating pulses of immigrants of both sexes even as late as at the end of May. This was also observed in 1998 and 1999 (Elgmork 2002) and reported by Nordby (1991) from a site about two $\mathrm{km}$ to the north.

Some preliminary bird observations from other parts of the municipality showed different assemblages, apparently influenced by local ecological conditions.

The average frequency of birds in each season was compared with average temperature and precipitation (Figure 2), and with duration of the snow cover for the same period. The analysis gave no statistically significant correlations.

The yearly frequency of individuals of each species throughout the twelve year study period 1997 2008 is presented in Figure 9. The Great and Blue 

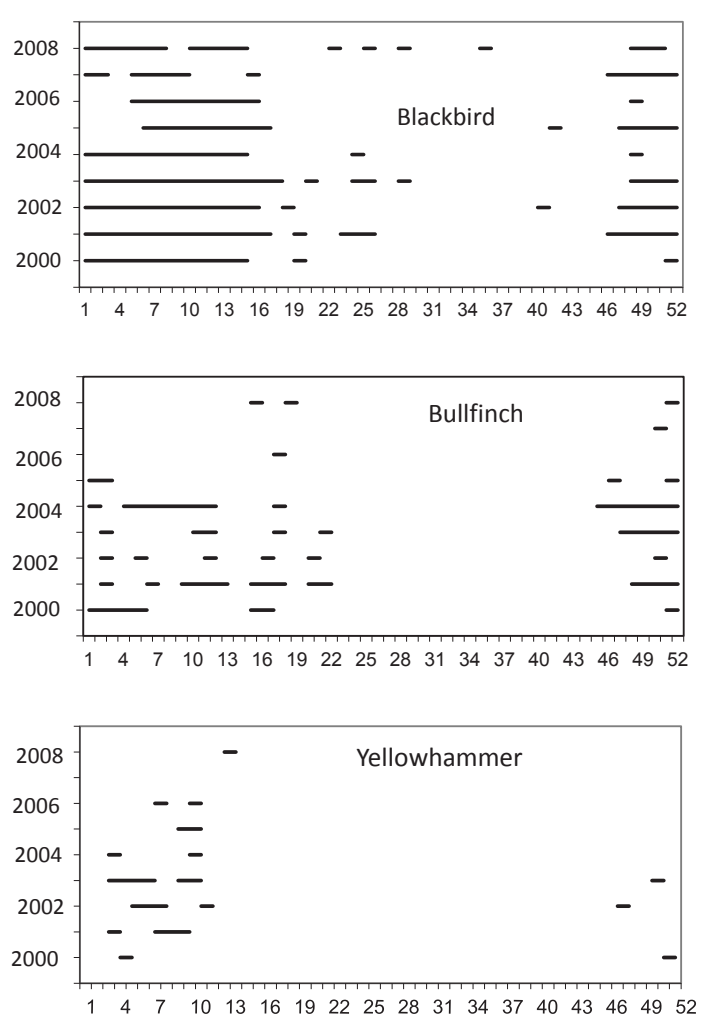

Figure 8. Yearly frequencies of species present primarily during winter. Legend as in Figure 4.

Arlig frekvens för arter som registrerades främst under vintern. Förklaring som i Figur 4.

Tit showed very similar occurrence with very high and stable frequencies each year, except for an intermediate falling trend in the Blue Tit. Greenfinch, Tree Sparrow, Collared dove, Blackbird, Robin, Woodpigeon, and Chaffinch showed maxima in the middle of the period from 2000-2002. The rest of the species showed a more erratic occurrence over the years. In Figure 9, I compare the results from my study site with those from the national survey of breeding birds in Norway 1997-2008 (Huseby \& Stueflotten 2009). Generally, the yearly fluctuations are greater at the study site than in the national survey. This is especially so for the two invasion species Siskin and Redpoll which showed large maxima in 1999 and 2003 at the feeding site. This indicates that some species show great local variation in occurrence. The yearly variation of the Siskin and Redpoll at the feeding site was significantly correlated $(0.66, \mathrm{P}=0.02, \mathrm{~N}=12)$.
Some species showed a corresponding variation in occurrence at the study site and in the national survey. This is apparent for the Bullfinch, the Nuthatch, and the Greenfinch. If the sum of all the 13 shared species in the two data sets are compared, a close correlation was found between the study site and the national survey $(\mathrm{r}=0.59, \mathrm{P}=0.04, \mathrm{~N}=12)$ (Figure 9). A similar comparison with the Swedish survey with 15 species (Lindström et al. 2009) exclusive of the Collared Dove and the Hawfinch, gave no significant correlation $(0.43, \mathrm{P}=0.16$, $\mathrm{N}=12$ ).

\section{Habitat change and reduced bird diversity}

When comparing the bird assemblage at the study site with that in the continuous forests to the northwest about $4 \mathrm{~km}$ away (Figure 1), great differences are revealed. This comparison became possible due to a detailed study by Hogstad (1968) using a strip survey method during the period May 1966 to May 1967. The types of forest surveyed were spruce dominated forests and mixed forest edge. Altogether 132 surveys were made, an average of 11 per month. It seems legitimate to use so old results for comparison with the present situation as no major changes are expected to have taken place in overall assemblage composition in the forest. The comparison reveals profound differences both in number of species and in frequencies (Table 2).

Only three species were found only at the study site. The remaining fourteen species in Table 2 are regularly present both at the study site and in both types of forest. In the forest assemblage the Bullfinch, Willow Tit Poecile montana, Jay Garrulus glandarius, and the Goldcrest Regulus regulus were present throughout the year. The 21 species at the bottom of Table 2 were found only in the forest, some occasionally occurring at the study site as single individuals at extremely low frequencies (Table 1). This means that only $36 \%$ of the spruce forest assemblage occurred regularly at the study site in the suburban area. This is a dramatic reduction showing that when forest habitats are transformed into agricultural and suburban areas, a considerable loss of diversity ensues.

\section{Rate of consumption}

The consumption of sunflower seeds as grams per day on average per week is shown in Figure 10. The tit balls were not used in this experiment. During periods of intense feeding, the food box, containing one kilo of seeds, was eaten empty during 
Table 2. Comparison of the Jar garden community with a neighbouring forest community, according to Hogstad (1968). The values give the number of months during a year that the species have been observed. * accidental observations 1997-2008. Bold: Maximum record for that species.

Jämförelse mellan fågelsamhället $i$ trädgården $i$ Jar och det $i$ ett närliggande skogsområde enligt Hogstad (1968). Värdena anger antalet månader under året så arten observerats. * tillfällig observation 1997-2008. Fet stil: högsta noterat värde. Kolumnerna avser granskog, skogskan med blandskog respektive trädgården i Jar.

\begin{tabular}{|c|c|c|c|}
\hline Species & Spruce forest & Mixed forest edge & Jar site \\
\hline House Sparrow Passer domesticus Gråspurv & 0 & 0 & 3,1 \\
\hline Tree Sparrow Passer montanus Pilfink & 0 & 0 & 9,6 \\
\hline Collored Dove Streptopelia decaocto Tyrkerdue & 0 & 0 & 3 \\
\hline Wood Pigeon Columba palumbus Ringdue & 5 & 1 & 3,7 \\
\hline Magpie Pica pica Skjære Skata & 8 & 10 & 12 \\
\hline Great Tit Parus major Kjøttmeis Talgoxe & 11 & 10 & 12 \\
\hline Blue Tit Cyanistes caeruleus Blåmeis & 7 & 10 & 11,2 \\
\hline Nuthatch Sitta europea Spettmeis Nötväcka & 4 & 8 & 4,9 \\
\hline Blackbird Turdus merula Svarttrost Koltrast & 8 & 7 & 4,7 \\
\hline European Robin Erithacus rubecula Rødstrupe & 7 & 5 & 3,2 \\
\hline Greenfinch Carduelis chloris Grønnfink & 10 & 9 & 10 \\
\hline Siskin Carduelis spinus Grønnsisik & 9 & 5 & 1,9 \\
\hline Redpoll Carduelis flammea Gråsisik & 0 & 6 & 0,6 \\
\hline Bullfinch Pyrrhula pyrrhula Dompap & 12 & 9 & 2,4 \\
\hline Chaffinch Fringilla coelebs Bokfink & 6 & 4 & 4,3 \\
\hline Brambling Fringilla montifringella Bjørkefink & 6 & 5 & 1,1 \\
\hline Yellowhammer Emberiza citrinella Gulspurv & 8 & 9 & 0,6 \\
\hline Hooded Crow Corvus corone cornix Kråke & 11 & 10 & $*$ \\
\hline Treecreeper Certia familiaris Trekryper & 10 & 5 & * \\
\hline Black Woodpecker Dryocopus martius Svartspett Spillkråka & 11 & 6 & 0 \\
\hline Wren Troglodytes troglodytes Gjerdesmett Gärdsmyg & 7 & 5 & * \\
\hline Fieldfare Turdus pilarus Gråtrost Björktrast & 8 & 7 & * \\
\hline Songthrush Turdus philomelos Måltrost Taltrast & 7 & 4 & 0 \\
\hline Redwing Turdus iliacus Rødvingetrost & 7 & 6 & * \\
\hline Willow Tit Poecile montana Granmeis Talltita & 12 & 2 & 0 \\
\hline Crested Tit Lophophanes cristatus Toppmeis Tofsmes & 11 & 1 & * \\
\hline Garden Warbler Sylvia borin Hagesanger Trädgårdssångare & 2 & 2 & 0 \\
\hline Chiffchaff Phylloscopus collybita Gransanger & 5 & 3 & 0 \\
\hline Willow Warbler Phylloscopus trochilus Løvsanger & 4 & 2 & 0 \\
\hline Jay Garrulus glandarius Nøtteskrike & 12 & 7 & 0 \\
\hline Goldcrest Regulus regulus Fuglekonge & 12 & 5 & 0 \\
\hline Hedge Accentor Prunella modularis Jernspurv & 5 & 2 & * \\
\hline White Wagtail Motocilla alba Linerle Sädesärla & 2 & 4 & * \\
\hline Long-tailed Tit Aegithalos caudatus Stjertmeis & 1 & 1 & 0 \\
\hline Green Woodpecker Picus viridis Grønnspett & 1 & 3 & 0 \\
\hline Tree Pipit Anthus trivialis Trepiplerke & 3 & 1 & 0 \\
\hline Periparus ater Parus ater Svartmeis & 11 & 0 & 0 \\
\hline Hazel Grouse Tetrastes bonasia Jerpe & 1 & 0 & 0 \\
\hline Woodcock Scolopax rusticola Rugde Morkulla & 3 & 0 & 0 \\
\hline Crossbill undet. Loxia sp. Korsnebb & 7 & 0 & 0 \\
\hline Starling Sturnus vulgaris Stær & 0 & 5 & * \\
\hline Marsh Tit Poecile palustris Løvmeis Entita & 0 & 9 & 0 \\
\hline
\end{tabular}



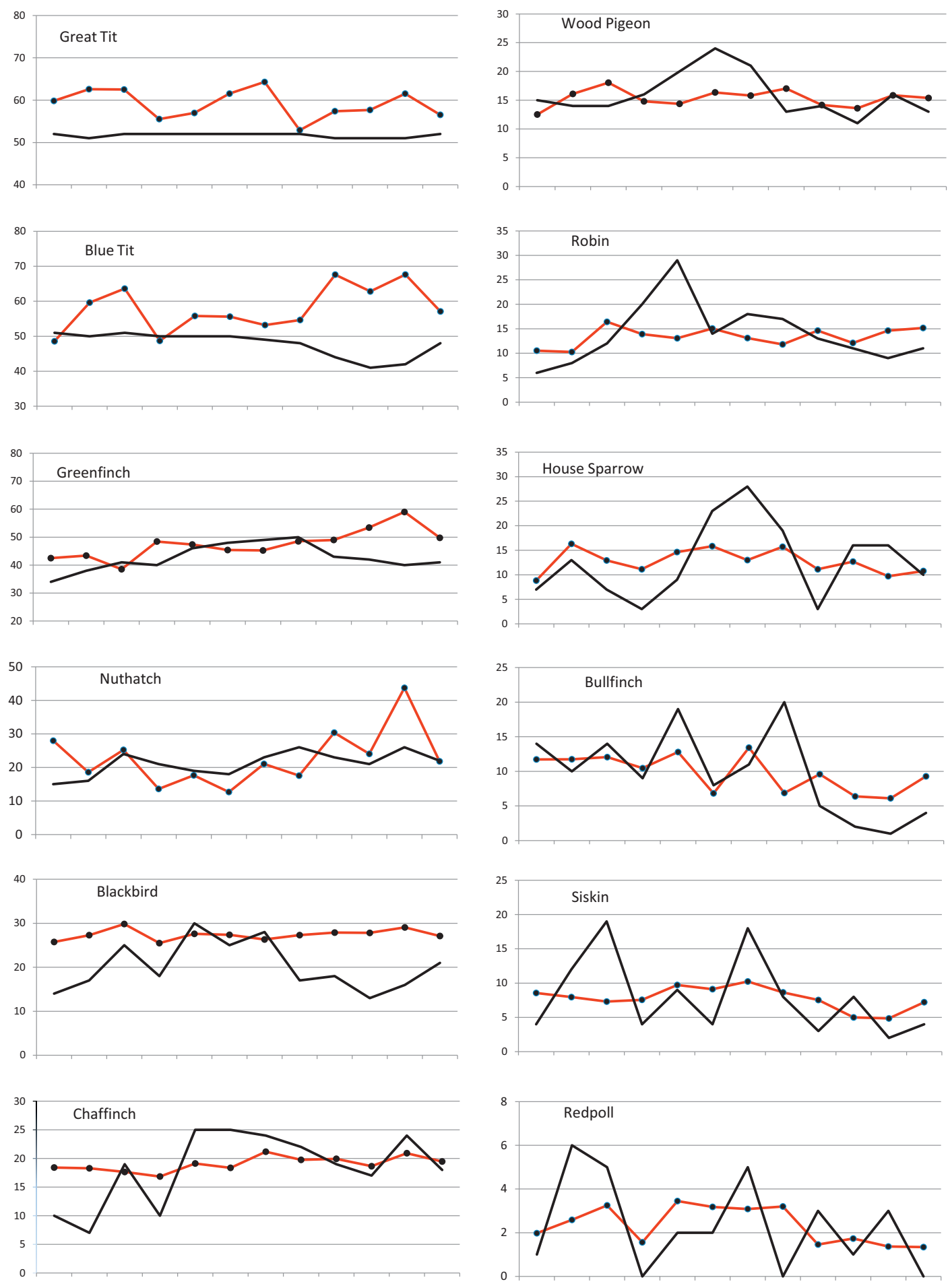

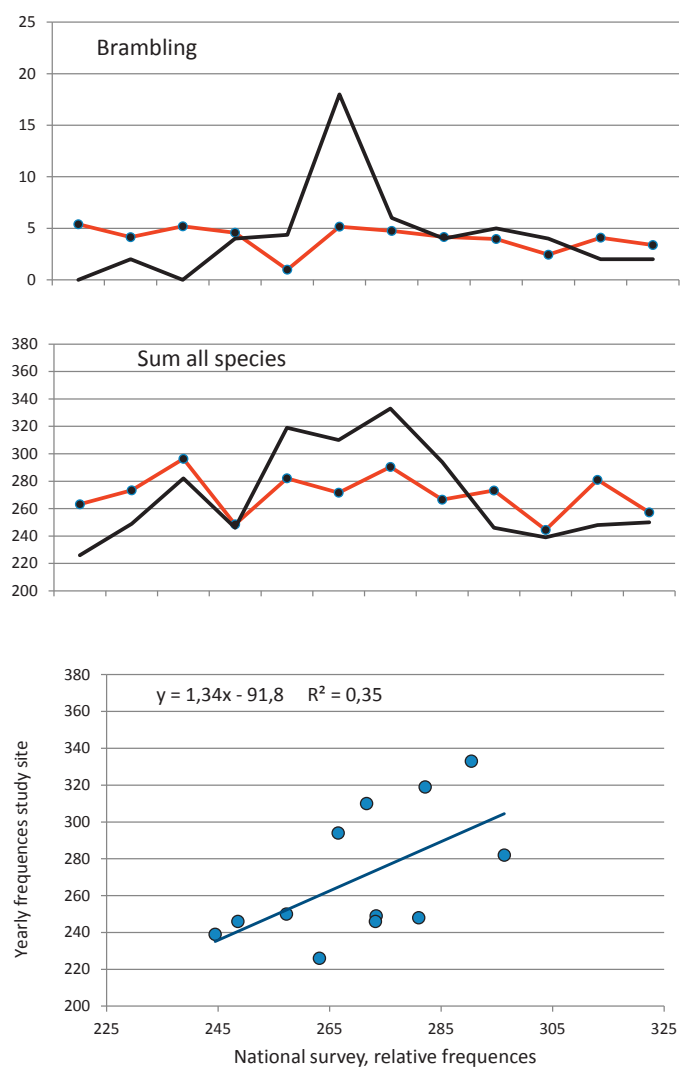

Figure 9. Variation of single bird species at the study site (black line) compared with results from the national survey of breeding birds in Norway (red line) in the period 19972008. The vertical axis represents relative values to make the curves fit in the diagrams. The last two diagrams compare the whole assemblage of birds at the study site and in the national survey.

Variationen hos enskilda arter $i$ den studerade trädgården (svart linje) och enligt den norska häckfägeltaxeringen (röd linje) perioden 1997-2008. Vertikala axeln representerar relativa värden. De sista två diagrammen avser summan av alla arter.

one day. As seeds fallen to the ground was eaten during the following day, a minimum consumption time was set to two days, giving $500 \mathrm{~g}$ eaten maximally per day.

The highest rate of consumption occurred in summer and autumn with lower values during the other seasons. Minimum consumption was observed in late winter and spring when it could take up to 88 days to eat down one kilo of seeds. Record in consumption rate was set in July 2003 when the feeding cylinder was empted in the course of 4 hours, mainly by Greenfinch and Tree Sparrow and their young.

To avoid statistical noise the year was divided into three months intervals and average consumption for each interval was correlated with average temperature and precipitation (Figure 2). Precipitation during January-March was represented by the duration of the snow cover. No significant correlation could be traced between seasonal consumption and climatic factors.

The period April-June was characterized by very rapidly increasing consumption, especially in May. In the years 2002, 2003, and 2004 there was an early maximum followed by a period of lower consumption. This maximum may indicate a wave of immigrants. This was not recorded, however, in the four last years of study.

Consumption during July-September was relatively stable with long periods of maximum consumption, except in 2004, when a reduction started already in July under medium temperature and precipitation. Also the summer of 2005 showed low values. High consumption values occurred in 2003, 2007 , and 2008, but there was no significant correlation to temperature or precipitation. If the week numbers of the first summer maximum are correlated with average temperature of the foregoing spring, no correlation was found $(\mathrm{r}=0.13, \mathrm{P}=0.77$, $\mathrm{N}=7$ ). The correlation with precipitation was negative, but not quite significant $(-0.69, \mathrm{P}=0.09, \mathrm{~N}=7)$, indicating that a high precipitation in spring may lead to an earlier summer maximum.

A marked decrease in consumption during all seven years of study took place in October-December, starting usually in October or November. A cold period followed by the first snow in autumn trigger two reactions. Firstly, a sharp rise in consumption in the years 2002-2005 indicates extraordinary high intake of food by the birds present. An increase in the number of birds is unlikely as the maxima are very short and it is unreasonable that new flocks of birds should occur exactly in the same setting every year. The increase in consumption was followed by an abrupt fall in consumption in all years synchronous with the first snowfall, marked with an asterisk in Figure 10. The fall took place from none to two weeks after the first snowfall in six of seven years. In 2007, however, the decline occurred shortly before the snowfall. The decrease continued even if temperature was increasing later in the autumn. This indicates a regular emigration out of the area in autumn. 

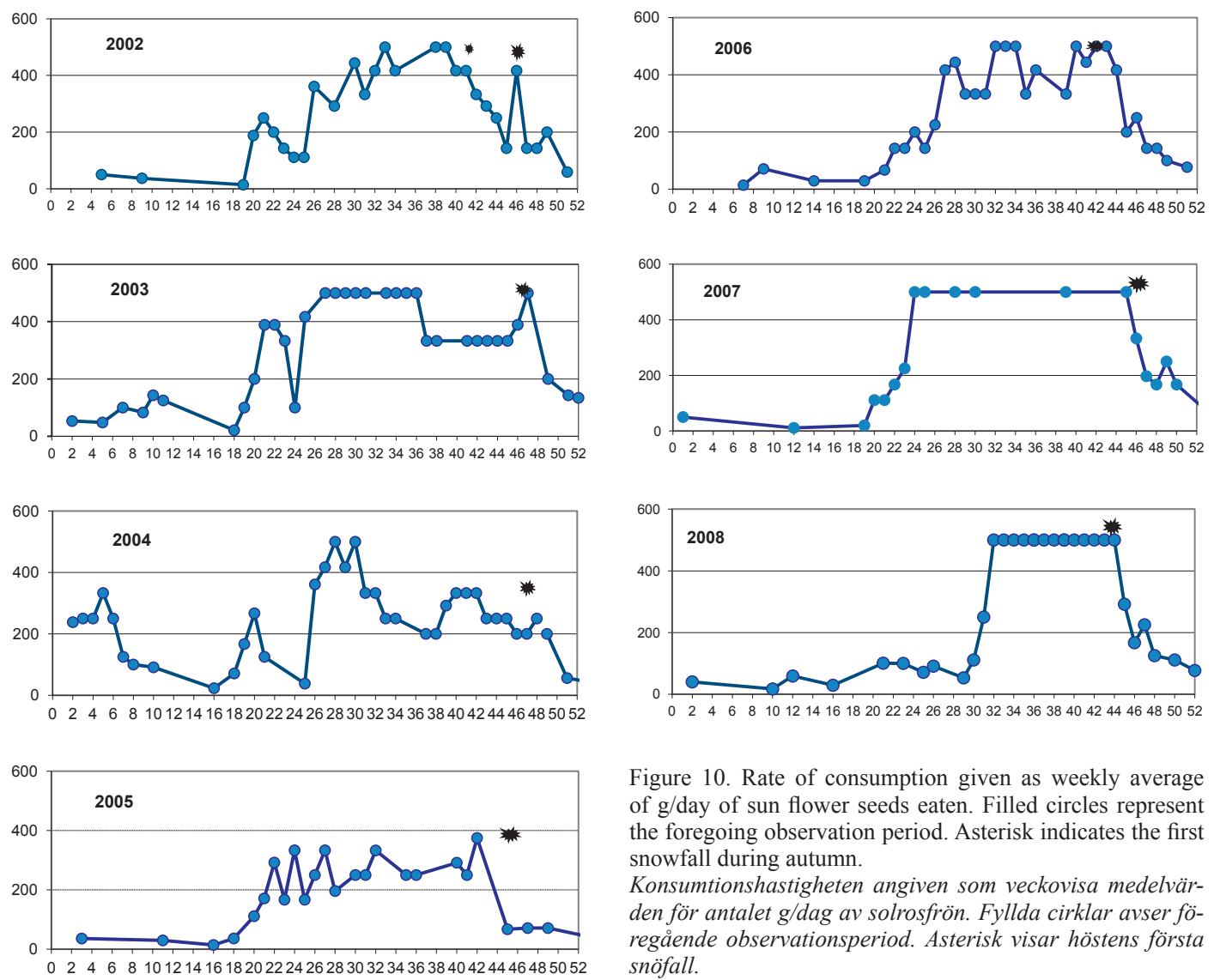

Figure 10. Rate of consumption given as weekly average of g/day of sun flower seeds eaten. Filled circles represent the foregoing observation period. Asterisk indicates the first snowfall during autumn.

Konsumtionshastigheten angiven som veckovisa medelvärden för antalet g/dag av solrosfrön. Fyllda cirklar avser föregående observationsperiod. Asterisk visar höstens första snöfall.

\section{Discussion}

The large frequency of the Great Tit and Blue Tit is in accordance with the presence of these species in the Nordic countries. According to breeding bird surveys in Norway, Sweden, Denmark, and Finland (Heldbjerg \& Eskildsen 2009), the Great Tit is the garden bird number one in these countries, seen in $90 \%$ of the gardens. Number two is the Blue Tit, seen in $80 \%$ of the gardens.

The species observed at the feeding site do not represent the true assemblage of birds in the area. The restricted feeding with only seeds and fat reduces or excludes species with other food preferences as insect eaters. This is borne out by the presence in the same garden of other species never seen on the feeding site. Such species were the Pied Flycatcher Ficedula hypoleuca, White Wag-

tail Motacilla alba, and Lesser Whitethroat Sylvia curruca. Maximum consumption during summer in the present study is inconsistent with the results of Cowie \& Hinsley (1988) who found maximum consumption during the winter in England. The most common species in both studies were the Great Tit, Blue Tit, and Greenfinch. In the English study, also the House Sparrow was common.

The close relation between the sum of species in the study area and in the national survey indicates that the birds at the study site vary in concert with birds in a much wider area. Some overriding, universal factor or factors must regulate the number of birds synchronously over vast areas of Norway. Testing climatic factors is problematic as the climate varies considerably over the country. Lack of correlations with climatic factors in the study area seems to disqualify the climate as a regulatory factor. 


\section{Acknowlegements}

I am grateful to Magne Husby, Trondheim, and Åke Lindström, Lund, for help in obtaining data from the respective national breeding bird surveys in Norway and Sweden.

\section{References}

Cowie, R.J. \& Hinsley, S.A. 1988. The provision of food and the use of bird feeders in suburban gardens. Bird Study 35: $163-168$.

Elgmork, K. 2002. Seasonal variation of birds on a feeding site in a suburban area near Oslo, Norway. Fauna norv. 22: $1-8$.

Heldbjerg, H. \& Eskildsen, A. 2009. Overvågning af de almindelige fuglearter i Danmark 1975-2008. Arsrapp. Dansk Ornit. For. 2009.

Hogstad, O. 1967. Seasonal fluctuations in bird populations within a forest area near Oslo (southern Norway) in 196667. Nytt Mag. Zool. 15: 81-96.

Husby, M. \& Stueflotten, S. 2009. Norsk hekkefugltaksering. Bestandsutvikling i HFT- områdene for 57 arter 1995-2008. Norsk Ornit. For. Rep. 6, 2009: 1-33.

Lindström, Å. \& Green, M., Ottvall, R. \& Svensson, S. 2009. Monitoring population changes of birds in Sweden. Ann. Rep. 2008. Department of Ecology, Lund University. 80 pp.

\section{Sammanfattning}

Under nio år (2000-2008) har antal fåglar som besökte en matplats med solrosfrön och talgbollar räknats dagligen året om med bara några få korta avbrott. Dessförinnan hade fåglarna räknats mindre frekvent än dagligen under tre år, räkningsperioden är alltså tolv år lång. Platsen är en villaträdgård $\mathrm{i}$ Bærum, ett villaområde beläget mellan Oslo city och sammanhängande skogar (Figur 1). Matningsplatsen låg $2,5 \mathrm{~m}$ från ett stort köksfönster från vilket alla observationer gjordes. Klimatet framgår av Figur 2, som visar temperatur och nederbörd i form av årstidsmedelvärden. En äldre kvantitativ och detaljerad inventering året runt av fågelfaunan i skogsområdet gjorde det möjligt att jämföra skogen fågelfauna med den i villaområdet. Vanliga namn på fågelarterna tillsammans med engelska och latinska finns i Tabell 2.

De fyra mest frekventa besökarna var talgoxe, blåmes, grönfink och pilfink (Figur 3). En del sällsynta arter registrerades (Tabell 1) men en av de arter som förekom åren 1997-1999, turkduvan, saknades helt under den efterföljande nioårsperioden. Fåglarnas säsongsmässiga variation presenteras i Figurerna 4-8. De har grupperats med hänsyn till sina förekomstmönster under året. De nyssnämnda fyra arterna som förekom mest frekvent visas i Figur 4. Antalet grönfinkar och pilfinkar ökade från vecka 26 och 27 beroende på att årets ungfåglar dök upp. Figur 5 redovisar arter med mera oregelbundet uppträdande, och dessa arter är invasionsarter, förutom rödhake och stenknäck. Rena sommarfåglar (Figur 6) var bofink och ringduva. Några arter (Figur 7), exempelvis gråsparv, iakttogs främst under sommar och höst men bara sällan under vintern. Vinter- och vårarter (Figur 8) var koltrast och domherre. Den senare arten har varit fåtalig de senaste åren men uppträtt stötvis på våren ända in i slutet av maj. En analys av väderdata och fågelförekomst visade inget samband med temperatur, nederbörd eller snöperiodens längd.

I Figur 9 visas de olika arternas och hela fågelsamhällets årliga förekomst vid matningen i förhållande till det nationella beståndet som det registreras av den nationella häckfågeltaxeringen. Flera arter visade tydlig samvariation och för summorna för tretton arter som var med i båda räkningarna var korrelationen signifikant. Motsvarande korrelation med den svenska häckfågeltaxeringen visade däremot inte någon signifikans.

I Tabell 2 redovisas frekvensen för fåglarna i trädgården och i det inventerade skogsområdet bara fyra kilometer därifrån. Det var stora skillnader. Bara tre arter enbart i trädgården. Fjorton arter registrerades både i trädgården och i skogen, medan majoriteten av arterna bara fanns i skogen. När en skog omvandlas till villaområde förloras alltså en mycket stor del av den biologiska mångfalden.

\section{Kåre Elgmork 1924-2011}

This article is published posthumously. Kåre Elgmork died on 19 November 2011, only a few weeks before his 87 th birthday. He had just prepared the letter to offer the paper for publication in Ornis Svecica. Kåre Elgmork was professor of zoology, studied first copepods, and then the brown bear. He was deeply engaged in conservation, and for his achievements in this field he was the second person in Norway on whom the Order of St. Olav was conferred. He was also an ornithologist. In his later years he could no longer walk in the fjelds and woods. Instead he counted the birds at his feeder every day for years. The editor thanks Viggo Ree, who saw to that the manuscript was transferred to Ornis Svecica. 